\title{
K MOŽNOSTEM PŮSOBENÍ SOCIÁLNÍCH VĚD A SOCIOLOGIE VE SPOLEČNOSTI
}

\author{
JÁN MIŠOVIČ \\ Teologická fakulta Jihočeské univerzity \\ E-mail: misovic@tf.jcu.cz
}

V našem odborném diskurzu se věnuje působení společenských věd ve společnosti nevelká pozornost. Přitom jeden z významných sociologů, americký autor C. Wright Mills, na téma upozorňoval ve své knize Sociologická imaginace, jejíž 60. výročí vydání jsme si v roce 2019 připomenuli. Oba momenty jsou dobrým důvodem pro to, abychom se na tento námět soustředili. Bez nároků na hlubší rozbor se domnívám, že i v dnešní době stojí za pozornost charakterizovat obecnější i konkrétnější otázky spojené s působením sociálních věd, původně nastíněné Millsem už v roce 1959. Jednou z cest, jak o nich pojednat, je připomenout si jeho úvahy o možnostech, jež se k tématu vztahují.

Z mnoha jeho myšlenek orientovaných na podstatu sociálního poznání se zastavíme u jedné z nich. Podle Millse „ani někdejší liberální praxe ani byrokratická sociální věda se nezabývají závažnými veřejnými problémy a osobními starostmi lidí tak, aby je učinili součástí problémů sociální vědy“ (Mills, 2008, s. 141). O co by tedy, podle Millse, mělo jít sociálním vědám? Odpovídá: věnovat pozornost závažným veřejným problémům, které jsou úzce spojeny s osobními starostmi lidí. Oprávněně vyvstává otázka, zda se sociologové nesoustředují na osobní starosti lidí. Mills uznává, že liberální sociologové se zabývali v minulosti osobními obtížemi lidí až př́lišs, na úrovni samotných obtíží. Přitom zapomněli na hodnoty, z nichž problémy vyplývaly, stejně jako na rozpracování či porovnání strukturálních podmínek, jež vedly k pochopení těchto obtíží (ibid.). Miloslav Petrusek jinými slovy vyjadřuje požadavky, jejichž naplnění Mills spojuje s uplatněním sociální vědy. Hovoří o dvou jejich dimenzích: (a) dimenzi makrostrukturálně kriticko-analytické, která se realizuje předmětným zkoumáním a kritickým posuzováním „velkých problémů doby“, dopadajících do reálných životů obyčejných lidí, respektive rozborem „dialektiky velkých a malých dějin“, (b) dimenzi kriticko-reflexivní, jako nástroji kritického myšlení, týkajícího se samotné reality, ale také způsobu jejího poznávání (Petrusek, 2008, s. 277). Sám Mills vyjádřil základ nastíněné problematiky prostřednictvím několika obecných tezí: (a) podstatný výsledek sociálněvědního počínání, určování faktů, má politický význam; (b) sociální věda představuje podle něj veřejný zpravodajský aparát, orientovaný na závažné veřejné problémy, osobní starosti lidí i strukturální funkce doby; (c) každý sociální vědec musí diferencovat mezi tím, o co se lidé zajímají, a tím, co je v jejich zájmu (Mills, 2008, s. 193-210). Jaké cesty vedou k naplnění uvedených požadavků, to se pokusím naznačit v následující časti, prostřednictvím funkcí a dimenzí sociologie, vztahu sociálněvědního poznání a politiky, ontologické a epistemologické stránky sociální vědy. 


\section{Funkce a dimenze sociologie}

Funkce sociologie se spojují s jejími třemi běžně uváděnými podobami, jimiž tato sociální věda reflektuje společenské dění a reaguje na něj: funkcí poznávací, sociotechnickou a kritickou. První dvě funkce se stávají více méně samozřejmou součástí fungování sociologie jako teoreticko-empirické vědy (Berger, 1991, s. 48; Zich, 2003, s. 7-8).

Třetí funkce, kritická, není automaticky přítomna v úvahách a koncepcích sociologů, tak jako kritičnost není nutnou, apriorní charakteristikou myšlení. Platí i pro sociologii, že kritický postoj je třeba vědomě uplatňovat (Nohejl, 2007, s. 157). Kritika představuje takový nástroj, který proměňuje abnormalitu v normalitu. Přitom kritika je sama o sobě „abnormalitou“, protože vnáší do všeobecně akceptovaného uspořádání řadu vnějších obrazů, které se liší od dosavadního vnitřního uspořádání strukturních prvků a pravidel. O takto pojatou kritiku se opírá kritická teorie, zohledňující společenskou determinaci objektů vědeckého poznání i samotných poznávacích subjektů. „Člověk se tedy stal výslednicí sil, jimiž na něj působí okolí, avšak i entitou, z níž lze tyto vlivy zpětně analyzovat" (Nohejl, 2007, s. 159). Základním projevem kritické teorie je reflexivita, která však nezůstává bez důsledků a v nejkrajnějším případě vede ke strukturálním změnám posuzované skutečnosti (Nohejl, 2007, s. 159). Mills v této souvislosti volá po záměrném předkládání kontroverzních teorií a aktivním podněcování polemik (Mills, 2008, s. 207).

Jeden $\mathrm{z}$ autorů, který navazuje na požadavky Millse kladené na sociology, je bývalý prezident Mezinárodní sociologické asociace (ISA), dříve představitel Americké sociologické asociace (ASA), Michael Burawoy. Spolu s funkcemi sociologie uvažuje rovněž o jejich dimenzích. Ve svém nástupním projevu před americkými kolegy v roce 2004 reflektoval spolu s jednotlivými funkcemi sociologie i jednoduché schéma ideálně typických dimenzí sociologie: aspektu profesionálního, kritického, expertního a veřejného (viz Tabulku).

\begin{tabular}{|l|l|l|}
\hline Proměnné & Akademické publikum & Mimoakademické publikum \\
\hline Instrumentální vědění & Profesionální & Expertní \\
\hline Reflexivní vědění & Kritická & Veřejná \\
\hline
\end{tabular}

Tabulka: Čtyři dimenze sociologie (zdroj: Burawoy, 2005, s. 11; Stöckelová, 2012, s. 32).

Čtyři aspekty jsou definovány prostřednictvím dvou proměnných. První souvisí s tím, zda vytvořené poznatky mají instrumentální nebo reflexivní charakter, a druhá, zda se uživatelé, jimž jsou poznatky určeny, rekrutují především z akademické či neakademické sféry. Profesionální a kritická sociologie oslovuje akademickou sféru a expertní a veřejná sociologie neakademickou oblast (Burawoy, 2005, s. 10-11). ${ }^{1}$ Autor rovněž zdo̊razňuje, že profesionální sociologie vytváří základ, o který se další dimenze opírají, současně však připouští, že právě tato sféra sociologie je v rámci Spojených států amerických dominující a rozvíjí se na úkor ostatních oblastí, zejména veřejné sociologie. Snad je možné dodat, že to není jen situace typická pro USA. Burawoy se dotýkal i charakteristiky expertní

1 Veřejný význam sociologie a její kritickou funkci zdůrazňuje i Pierre Bourdieu (2013, s. 141-148). 
sociologie, která souvisí s jejím širokým zájmovým zaměřením, tvořeným nejen pouze státními a politickými institucemi, ale také mediální, podnikatelskou a nevládní sférou (Burawoy, 2005, s. 10-11). Burawoy připisuje současné sociologii s jejími funkcemi a aspekty specifickou roli mezi sociálními vědami, v podobě obhajoby společnosti před komercionalizací a hlediskem trhu na jedné straně, a hlediskem státu na straně druhé (Burawoy, 2005, s. 24; Stöckelová, 2012, s. 49). Odkazuje na mistrovství Millse v oblasti veřejné sociologie (Burawoy, 2005, s. 9) a hovoří o tom, že rozdělena na tradiční a organickou ${ }^{2}$ reprezentuje zájmy humanity, zájmy vzdálené „despotismu“ státu a tyranii trhu.

Na myšlenky Wrighta Millse navázala ve zcela jiné společenské situaci svým způsobem tehdejší představitelka Ruské sociologické asociace Tatána Zaslavská, a sice tím, že se zamyslela nad úlohou sociologie, když se v roce 1996 vyslovila k podílu sociologů na transformačním procesu ruské společnosti. V úvodu svého článku zdůraznila, že sociologie stejně jako další sociální vědy nesou určitou odpovědnost za způsob, jakým byla reforma prováděna. Přiznává vlastní chybu a konstatuje, že pokud sociální vědy chtěly být skutečně užitečné, jejich povinností bylo hledat a systematicky diskutovat a ovlivňovat procesy transformace vzhledem k možnostem ruské společnosti (Zaslavskaja, 1997, s. 29-30). Podle ní současná ruská sociologie plní tři hlavní funkce. První je vnitřní, shromažduje základní poznatky o struktuře a fungování společnosti a může být označena jako vědecko-kognitivní funkce. Druhou funkci nazývá politickou. Ta reflektuje spolupráci sociologie se státními orgány a nabízí pomoc při efektivním řízení společenského rozvoje. Třetí funkce je spojena s vytvářením občanské společnosti. Tuto funkci nazývá občanskou funkcí sociologie (Zaslavskaja, 1997, s. 34). Zaslavská konstatuje, že tato věda stále není připravena plně a profesionálně participovat na vědeckém př́istupu ke společenským reformám. Současně uvedla hlavní důvody, k nimž patří: nedostatek spolehlivých a přesných aktuálních poznatků o sociální struktuře, o institucích a jejich fungování, relativně málo rozvinutá všeobecná teorie postsovětské společnosti, jež by mohla posloužit jako metodologický základ pro oborové sociologické disciplíny (Zaslavskaja, 1997, s. 37). Rozvoj takové koncepce se podle ní stává hlavním úkolem nejen sociologie, ale i dalších sociálních věd (Zaslavskaja, 1997, s. 38).

Nabízí se otázka do diskuse, do jaké míry je schéma týkající se forem, dimenzí, uvedených funkcí sociologie i jejího samotného stavu aplikovatelné i na ostatní sociální vědy. Pokud připouštíme, že i další sociálněvědní disciplíny se vyznačují podobnými funkcemi a aspekty jako sociologie, tak jejich působení může být významnější, než se obvykle předpokládá.

\section{Ke vztahu sociálněvědního poznání a politiky}

Druhé téma, které charakterizoval Mills jako základní, s prvním bezprostředně souvisí a týká se vztahu sociálněvědního poznání a politiky. Zahraniční sociologové se tímto

2 Tradiční veřejná sociologie se stala hybatelem veřejných diskusí o podobě americké společnosti, o jejich silných a slabých stránkách, o prevažujících tendencích. Za reprezentanty tohoto proudu kromě Millse bývá považován např́iklad Gunnar Myrdal (1944) nebo David Riesman (1950). Organická veřejná sociologie pracuje v úzkém spojení s aktivní místní veřejností, odborovým hnutím, občanskými sdruženími (srv. Burawoy, 2005, s. 7-8). 
tématem svým způsobem rovněž zabývali. Zaslavská píše o těžkostech spojených s přinášením doporučení těm, kteří řídí společnost. Na jedné straně je profesionální účast sociologů na reformách ztížena tím, že vládnoucí vrstva se nezajímá o spolupráci s nimi. $\mathrm{Na}$ druhé straně dochází $\mathrm{k}$ inflaci zpráv a programů odevzdávaných vědeckými institucemi vládním orgánům (Zaslavskaja, 1997, s. 38).

Burawoy v souvislosti s působením sociologie připomínal důležitost a nutnost posílení veřejné sociologie jako integrální součásti sociologické profese jak ve formě veřejné intelektuální produkce, tak prostřednictvím participativního výzkumu, ve spolupráci s komunitami, hnutími, veřejností.

Aktuální stav v této oblasti hodnotí americký sociolog Paul Nyden. Jádro diskuse týkající se veřejné sociologie v průběhu posledních dvou desetiletí je spojeno s otázkou, zda se sociologové spokojí s analýzou a popisem nesčetných společenských problémů nebo se budou více angažovat, pracovat s ostatními spolupracovníky a nalézat vhodná řešení těchto problémů (Nyden, 2010, s. 6). Autor konstatuje, že od projevu Burawoye se spojení mezi akademickou vědou a neakademickým světem rozšírilo. Tato skutečnost se promítá do př́nosu společně vytvořených projektů, $v$ rámci nichž se počítá s partnery z neakademické sféry ve všech fázích výzkumu (Nyden, 2010, s. 9). Podstata spolupráce spočívá v tom, že na vytváření poznatků se podílejí obě strany, nové informace vznikají na univerzitách i mimo ně (Nyden, 2010, s. 10). Realizace konkrétních projektů ukazuje posun od tradičního přístupu sociologie, spojeného s mapováním sociálních problémů, k přístupu obsahujícímu společenská řešení (Nyden, 2010, s. 18). Veřejná sociologie tak v žádném př́padě nemůže být označena jako druhořadá (Burawoy, 2005, s. 25).

Někteří kritici Burawoyova návrhu považují zdůrazňování významu veřejné sociologie za ohrožení objektivity a v důsledku toho i společenské autority a postavení sociologie jako vědy. Veřejná sociologie je podle nich projevem politického aktivismu maskovaného vědou a vnáší hodnoty do oblastí, v nichž nemají co pohledávat (Brint, 2007, s. 243-244, Turner, 2007, s. 280-281, Stöckelová, 2012, s. 34). Burawoy odmítá snahy svých oponentů, např́klad Jonathana Turnera, který pokládá veřejnou sociologii za patologickou formu sociologie. Stejným zpo̊sobem démonizuje i kritickou sociologii. Jiný kritik veřejné sociologie Steven Brint mu vyčítá, že charakterizuje politický aktivismus pomocí neutrálních pojmů (Burawoy, 2007, s. 317). Podle Burawoye však veřejná sociologie neznečištuje hodnotově neutrální vědu, je pouze explicitnější v tom smyslu, že zpřítomněné hodnoty v poznávacím procesu nezakrývá (Burawoy, 2007, s. 320-322). Ve stejném duchu uvažuje i český autor Jiří Musil, když se odvolává na Maxe Webera a Gunnara Myrdala v tom smyslu, že sociální vědy ukazují na základní hodnotící východiska a „názor, že může existovat vědecké poznání, které by vzniklo bez jakéhokoliv hodnocení, je naivním empiricizmem“ (Musil, 2012, s. 1012).

Tereza Stöckelová rovněž zdůrazňuje roli sociologie ve veřejném prostoru, když připomíná její hlavní působení rozšiřováním relevantní vědecké informace. Čím více je sociálněvědní poznatek či termín ve společnosti úspěšnější, respektive čím více ho lidé vezmou za svůj, tím se stává jako součást či výsledek vědeckého snažení viditelnější. Přijetí do obecného povědomí ho „osvobozuje“ od jeho vědecké specifičnosti a napomáhá v transformaci v to, co všichni vědí (Stöckelová, 2012, s. 40). Výzkumníci by měli ovšem pocitovat i určitou odpovědnost za produkované výsledky. Tato odpovědnost nekončí jejich publikací a „propuštěním do světa“, ale měla by zahrnovat rovněž „následnou péči“ 
o jejich pochopení a využití ve veřejné sféře (Stöckelová, 2012, s. 46). Takto věnovaná pozornost veřejně předloženým poznatkům se nespojuje s jejich výlučným „vlastnictvím“ a správností jediného možného výkladu, ale spíše se snahou ovlivňovat diskuse probíhající ve veřejném prostoru.

V úvaze o působení sociálních věd však nejde ani tak o jejich tradičně akceptovaný jednosměrný vliv na společnost, jako o komplexní pohyb vědění ve společnosti. Naši i zahraniční autoři si všímají toho, že sociální vědy ovlivňují společnost bez ohledu na přání výzkumníků, bez jejich plné kontroly, či uvědomění si tohoto působení (Stöckelová, 2012, s. 14). Právě v uvedeném kontextu se dostává do popředí souvislost sociálních věd a politiky. Ve vztahu k politice to znamená, že výzkumníci nemají příležitost vyhnout se politice v širokém slova smyslu a zároveň disponují jen omezenou možností politické poměry a užití své práce kontrolovat.

Vzniká otázka, jak mohou badatelé pěstovat, pokud možno, přiměřený vztah mezi odborností a politikou, když zároveň nemají dění pevně a spolehlivě pod kontrolou (Stöckelová \& Grygar, 2008, s. 76-77). Na základě mnohostranných zkušeností se nabízejí určité kroky. Za prvé nespojovat se s jednou vědní politikou, respektive „nepracovat na politickou objednávku“, ale vystavovat se různým podobám zadávané politiky, za druhé brát $\mathrm{v}$ úvahu vnější pohledy a to nejen $\mathrm{v}$ rámci př́íslušné vědní disciplíny či oborové debaty, ale i šířeji, na základě rozličných veřejných diskusí. To by však nemělo znamenat podlehnutí těmto diskusím, ale spíše prezentování jasných stanovisek, které mohou mít i antagonistický charakter (Stöckelová \& Grygar, 2008, s. 77). To vše je možné uskutečnit za podmínky, že sociální věda nikdy nepracuje přímo pro vládní struktury, a pokud to tak dělá, tak přestává být vědou (Zaslavskaja, 1997, s. 39).

\section{Sociální vědy v ontologickém a epistemologickém kontextu}

Sociální vědy a jejich praktiky, které společnost určitým způsobem ovlivňují či přetvářejí, je třeba rovněž vystavit zpětnému zkoumání. Jedním z takových způsobů je sledování dopadu cíleného a relativně kontrolovatelného vědění ve formě aplikovaného výzkumu či veřejného angažování, resp. veřejné a expertní sociologie.

Tomu však musí předcházet obecný pohled na zkoumanou realitu. Takový pohled nabízí kvantová mechanika již od 30. let 20. století. Ten se však v oblasti věd o společnosti nesetkává s velkým pochopením. Moderní západní věda se totiž opírá o principy metafyzického myšlení. John Law vyslovuje pět předpokladů, na kterých metafyzika stojí: Skutečnost je pro nás vnější, je nezávislá na našem jednání a zejména vnímání, skutečnost předchází člověka, je určitá a jedinečná v tom smyslu, že je prakticky stejná (Zaslavskaja, 1997, s. 39). Autor ve svých úvahách nepopírá existenci výše uvedených rysů skutečnosti. Tyto vlastnosti ale nepokládá za předem dané a naopak se snaží dokazovat, jak realita takové charakteristiky získává, jak je její vnějškovost, nezávislost, určitost a jedinečnost formována. Podle něj jsou tyto vlastnosti, tvořící ontologické podmínky moderní vědy, vyvolány z velké části vlivem přírodních a sociálních věd. Stanovisko k charakteru skutečnosti v uvedeném duchu nabízí Bruno Latour. Jedna z jeho myšlenek to dobře ilustruje: „Věci mají tu zvláštní vlastnost, že je nelze rozkládat na primární a sekundární kvality. Jsou příliš skutečné, aby byly nejasnými reprezentacemi, a př́liš sporné, neurčité, kolektivní, rozmanité a rozvratné, aby hrály úlohu 
pevných, odolných a nudných primárních kvalit, které vesmír obývají jednou provždy. Co mohou sociální, ale i přírodní vědy dělat, je reprezentovat lidem tyto věci se všemi jejich souvislostmi a v celé jejich neurčitosti“ (Latour, 2002, s. 16).

Na základě poznatků sociologie, která dokáže alespoň zčásti respektovat takto nazíranou společenskou realitu, představuje Stöckelová nástin epistemologického a ontologického působení společenských věd. Epistemologický přístup charakterizuje následovně: „V epistemologickém pojetí reprezentují (více či méně přesně) poznatky sociálních věd zkoumanou skutečnost. Tyto poznatky pak mohou, nebo nemusejí, vstupovat do praktického světa politiky, která zasahuje do skutečnosti“ (Stöckelová, 2012, s. 62). V epistemologickém pojetí aktéři zásadně neovlivňují proces poznání, pouze jej orientují na vybraná témata, předmět výzkumu nebo na aplikované formy výsledků (srv. Stöckelová, 2012, s. 63). I v tomto př́padě platí Millsova charakteristika epistemologie jako zkoumání povahy poznání (Mills, 2008, s. 66).

Tezi o ontologickém působení shrnuje do dvou základních bodů. „Za prvé, skutečnost je vždycky mnohonásobná a do jisté míry neurčitá. Každé její zurčitění je nejen epistémickou akcí, ale v širokém smyslu i také politickou volbou... Za druhé toto zurčitění se neodehrává jednoduše na epistemologické úrovni poznání, není více či méně přijatelným zjednodušením složité skutečnosti, ale má také ontologické důsledky“ (Stöckelová, 2012, s. 62).

$\mathrm{V}$ rámci ontologického pojetí sociálních věd je kladen důraz na obousměrné vazby mezi politikou, předmětem poznání a sociální vědou. Fakticky to znamená, že různě kombinované dvojice faktorů mohou být ovlivňovány třetím faktorem, např. politika usměrňuje předmět poznání a sociální vědu, či předmět poznání má vliv na politiku a sociální vědu nebo sociální věda intervenuje do předmětu poznání a politiky. V tomto kontextu se objevuje pojem „ontologická politika“, jenž naznačuje, že sociálněvědní metoda vždy konkretizuje skutečnost, kterou chce zkoumat a zaměřuje se na různé alternativy z bohaté, mnohovrstevnaté reality (Stöckelová, 2012, s. 62).

Nabízí se zobecnění, že sociální vědy jednoduše nejen reflektují změny společenské reality a zpětně je reprezentují, ale aktivně se mohou podílet i na jejich utváření nebo se zapojovat do reprodukce stávajících poměrů (Stöckelová 2012, s. 67). Jde o to, do jaké míry si to konkrétní sociální vědy prostřednictvím svých nositelů a představitelů připouštějí a uvědomují. Autorka se domnívá, že sociální vědy doprovázejí či možná kopírují společenskou dynamiku. Hovoří se i o jejich společném vývoji a hibernaci (tamtéž). Jde tedy o ontologicko-politické působení věd i v př́padě, že se snaží takový stav nepřipouštět, popírat či zakrývat. V praxi se sociální vědy projevují i jinak, méně viditelně, méně kontrolovaně, mimoděk. Jak poznamenávají někteří autoři, etablované sociálněvědní metodologie mají sklon reprodukovat stávající skutečnost, spíše než otevírat a zviditelňovat alternativní možnosti. Sociální vědy přispívají v určité míře $\mathrm{k}$ utváření skutečnosti a to nejen té, která je předmětem studia či prrímé výpovědi, ale i „vedlejších“ skutečností, o nichž se v jejich rámci „jen“ implicitně uvažuje (Stöckelová 2012, s. 56-57).

\section{Závěr}

Sociální vědy působí na společnost prostřednictvím celé řady různých funkcí a dimenzí, přičemž se projevují přímým či zprostředkovaným dopadem. Veškeré jejich pů- 
sobení se odehrává v určitém historickém kontextu a za reálných společenských okolností, modifikujících samotnou jejich roli. Sociologové by v každé historické etapě měli mít na mysli svou orientaci na závažné veřejné problémy, osobní starosti lidí i strukturální funkce doby a uvědomovat si vzájemné propojení každodenních závažných životních problémů s dynamikou struktury společnosti. Spolu s oslovováním akademické sféry by se měli uplatnit se svým poznáním i ve veřejném prostoru, aby si odborné poznatky osvojovala i širší veřejnost. Je jen na odbornících zabývajících se konkrétními vědami, jakým způsobem a z jakých hledisek dokáží kriticky reflektovat dopady své vlastní vědní disciplíny na jednotlivé oblasti života lidí a hodnotit její př́nos pro současný i př́iští humánní charakter lidského žití. Inspirací jim mohou být i stále aktuální myšlenky významného amerického sociologa C. Wrighta Millse.

\section{LITERATURA}

Berger, P. L. (1991). Pozvání do sociologie. Praha: Správa sociálního řízení FMO.

Bourdieu, P. (2013). Chvála sociologie. Sociologický časopis / Czech Sociological Review, 49(1), 141-148. Brint, S. (2007). Guide for the Perplaxed. On Michael Burawoy's Public Sociology. In L. T. Nichols (ed.), Public Sociology: The Contemporary Debate (s. 237-262). New Brunswick / London: Transaction Publishers.

Burawoy, M. (2005). For Public Sociology. American Sociological Review, 70(1), 4-28.

Burawoy, M. (2007). Third-Wave Sociology and the End of Pure Science. In L. T. Nichols (ed.), Public Sociology: The Contemporary Debate (s. 317-336). New Brunswick / London: Transaction Publishers.

Latour, B. (2002). Když věci vracejí úder: Co mohou sociálním vědám přinést „vědní studia“. Biograf 29, 41 odst. Dostupné on-line z: http://www.biograf.org/clanek.php?clanek=2901 (navštíveno 27. 5. 2020).

Law, J. (2004). After Method: Mess in Social Science Research. London / New York: Routledge.

Law, J., Ruppert, E., \& Savage, M. (2011). The Double Social Life of Methods. CRESC Working Paper Series 095. Dostupné on-line z: http://www.open.ac.uk/researchprojects/iccm/files/iccm/Law\%20Savage\%20Ruppert.pdf (navštíveno 27. 5. 2020).

Mills, C. W. (2008). Sociologická imaginace. Praha: Sociologické nakladatelství.

Musil, J. (2012). Poznání a jednání v sociální oblasti - variace na Weberovo téma. Sociologický časopis / Czech Sociological Review, 48(5), 1009-1016.

Myrdal, G. (1944). An American Dilema: The Negro Problem and Democracy. New York: Harper and Row.

Nohejl, M. (2007). Jednání, diskurz, kritika. Myslet společnost. Praha: Sociologické nakladatelství (SLON).

Nyden, P. W. (2010). Social problem or Social Solutions? The Role of Public Sociology in Addressing Contemporary Crisis. Michigan Sociological Review, 24(3), 5-18.

Nyden, P., Hossfeld, L., \& Nyden, G. (2011). Public Sociology: Research, Action and Change. Thousand Oaks: Pine Forge Press.

Petrusek, M. (2008). Charles Wright Mills v kontextu radikální sociologie. In C. W. Mills, Sociologická imaginace (s. 263-288). Praha: Sociologické nakladatelství (SLON).

Riesman, D. (1950). The Lonely Crowd: The Study of the Changing American Character. New Haven: Yale University Press.

Stöckelová, T., \& Grygar, J. (2008). Hrátky s čerty? Politické souvislosti a přesahy sociálněvědního výzkumu. Biograf 46, 43 odst. Dostupné on-line z: http://www.biograf.org/clanek.php?clanek=4604 (navštíveno 27. 5. 2020).

Stöckelová, T. (2012). Nebezpečné známosti. O vztahu sociálních věd a společnosti. Praha: Sociologické nakladatelství (SLON).

Turner, J. H. (2007). Is Public Sociology Such a Good Idea? In L. T. Nichols (ed.), Public Sociology: The Contemporary Debate (s. 263-288). New Brunswick / London: Transaction Publishers.

Zaslavskaja, T. (1997). The Role of Sociology in Russia's Transformation. Russian Social Science Review, 38(6), 28-39.

Zich, F. (2003). Úvod do sociologie. Praha: VŠFS. 